\title{
Pectinase production by Aspergillus niger isolated from decomposed apple skin
}

\author{
S. Islam, ${ }^{1}$ B. Feroza, ${ }^{2}$ A.K.M. R. Alam ${ }^{2}$ and S. Begum ${ }^{3 *}$ \\ ${ }^{1}$ Industrial Microbiology Section, Institute of Food Science and Technology (IFST), BCSIR, Dhaka-1205 \\ ${ }^{2}$ Department of Environmental sciences, Jahangirnagar University, Savar, Dhaka - 1342 \\ ${ }^{3}$ Department of Microbiology and Biotechnology, Jagannath University, Dhaka-1100, Bangladesh
}

\begin{abstract}
Pectinase activity among twelve different fungal strains, Aspergillus niger IM09 was identified as a potential one to produce maximal level $831 \mathrm{U} / \mathrm{g}$ at pH 4.0. Media composition, incubation temperature, incubation time, substrate concentration, aeration, inoculum size, assay temperature and nitrogen sources were found to effect pectinase activity. Moisture content did not affect the activity significantly. Media composition was varied to optimize the enzyme production in solid state fermentation. It was observed that the highest pectinase activity of $831.0 \mathrm{U} / \mathrm{g}$ was found to produce in presence of yeast extract as a nitrogen source in combination with ammonium sulfate in assay media. Aeration showed positive significant effects on pectinase production $755 \mathrm{U} / \mathrm{g}$ at $1000 \mathrm{ml}$ flasks. The highest pectinase production was found at $2 \mathrm{~g}$ pectin $(521 \mathrm{U} / \mathrm{g})$ used as a substrate. Pectinolytic activity was found to have undergone catabolite repression with higher pectin concentration (205 U/g at $5 \mathrm{~g}$ pectin). The incubation period to achieve maximum pectinase activity by the isolated strain Aspergillus niger IM09 was 3 days, which is suitable from the commercial point of view.
\end{abstract}

Keywords: Fungi; Aspergillus niger; Pectin; Pectinase; Solid-state fermentation

\section{Introduction}

Pectinolytic enzymes, responsible for the degradation of pectic substances are of great technical importance (Spanga et. al., 1995). The principal use of pectinase is to depolymerize and esterify plant pectin in fruits such as apples, lemons, cranberries, oranges, cherries, etc. (Neilsen et. al., 1991; White and White, 1997). The pectinases are also useful for extraction of oils, flavors and pigments from plant materials, preparation of cellulose fibers for linen, jute and hemp production (Castilho et. al., 1999), coffee and tea fermentations (Taragano et. al., 1997) and novel applications in the manufacture of oligogalacturonides as functional food components (Hang and Dornenburg, 2000). It was reported the increase applications for pectinase in textile sector to reduce textile effluent, while improving the quality of the textile substrate (Nikolov, 2003).

Utilization of agricultural and domestic waste is important to keep cleaning of the environment and also to save natural resources. The waste contains considerable amounts of carbohydrates capable of utilization by microorganisms, implying the significance of pectinase (Yoshikawa and Tsuetaki, 1979).
The expense of the production bars the commercialization of novel enzyme-sources although, using high yielding strains, optimal fermentation conditions and efficient enzyme recovery methods can reduce the cost. Therefore, the deep comprehension of various physiological and genetic aspects of pectinase is required for producing thermo-stable and acid stable strains of pectenolytic fungi (Phutela et. al., 2005).

Only a very few studies have been carried out on the microbial pectinase in Bangladesh. Utilization of Industrial waste and save huge amount of foreign currency are the main purpose of this research. Usually pectinases are imported from foreign countries for industrial use in exchange of foreign currency. So, prioritizing the biotechnological importance of fungi in the enzyme industry, the present paper reports the isolation of pectin degrading fungi from various sources.

\section{Materials and methods}

\section{Collection of microorganisms}

Twelve different fungal strains were collected from different soil and fruit samples. Soils were collected underneath the 
fruit trees (mango, jackfruit, guava and blackberry) around Jahangirnagar University, Savar and fruits (skins of mango, jackfruit, guava, apple, orange, malta and hog-plum) were collected from different markets (Mohammadpur, New market and Karwan bazaar). One mold was supplied from the Industrial Microbiology Section. For fungal strains, all of these samples are labeled as follows: Mango (Soil) $=\mathrm{P} 1$, Jackfruit $($ Soil) $=$ P2, Guava $($ Soil) $=$ P3, Blackberry $($ Soil $)=$ P4, Mango $($ Skin $)=$ P5, Jackfruit $($ Skin $)=$ P6, Guava $($ Skin $)$ $=\mathrm{P} 7$, Apple $($ Skin $)=$ P8, Malta $($ Skin $)=$ P9, Orange $($ Skin $)$ $=\mathrm{P} 10$, Hog-plum $($ Soil $)=\mathrm{P} 11$, Mold $=\mathrm{P} 12 . \mathrm{P}$ is pectinase.

\section{Isolation of fungi}

After successive dilution of the different samples were inoculated on potato dextrose agar (PDA) media and incubated at $30^{\circ} \mathrm{C}$ for 1-2 days. The growth of organism from PDA plate was transferred to PDA slant by inoculation with a sterile loop and incubated at $30^{\circ} \mathrm{C}$ for 3-5 days. For identification of specific strain for the selected fungal isolate, microscopic examination was done by tease mount technique (Baneke and Rogers, 1970).

\section{Medium and Culture Conditions}

The solid-state cultivation was carried out in medium composed of following composition in gram, (pectin, 1.0; urea, 0.3; saccharose, 3.1; $\left(\mathrm{NH}_{4}\right)_{2} \mathrm{SO}_{4}, 1.3 ; \mathrm{KH}_{2} \mathrm{PO}_{4}, 0.65$; starch, 1.0; $\mathrm{FeSO}_{4} .7 \mathrm{H}_{2} \mathrm{O}, 0.30$; wheat bran, 16.0 ; rice husk, $6.0 ; \mathrm{pH}$, 4.5-5.0) added in $500 \mathrm{ml}$ conical flask. The final moisture was adjusted to $70 \%$ by adding tap water. The flasks were inoculated with concentrated spore suspension and incubated at $30^{\circ} \mathrm{C}$ for 3 days. After incubation $100 \mathrm{ml}$ distilled water was added to each flask and allowed then to shake at 150 rpm for two hours at $30^{\circ} \mathrm{C}$ in an orbital shaker. The culture media was then filtered and centrifuged at $4000 \mathrm{rpm}$ for 5 minutes and the supernatants were preserved for determination of the enzyme activity.

\section{Assay of enzyme activity}

For pectinase assay suitably diluted $1 \mathrm{ml}$ enzyme solution was incubated with $5 \mathrm{ml}$ of pectin solution and $1 \mathrm{ml}$ of 0.05 $\mathrm{M}$ citrate buffer ( $\mathrm{pH}$ 5.5) was incubated at $40^{\circ} \mathrm{C}$ for $10 \mathrm{~min}$. The reducing sugar formed was estimated by Stiles et. al. (1926).

One unit of pectinase activity was defined as the amount of enzyme which liberated 1 micromole of galacturonic acid per minute under the above condition.
The selected strain which showed maximum enzyme production was used for the optimization of pectinase production. The effect of pectin composition (1-5 g), incubation period $(2-8$ days $)$, temperature $\left(30-50^{\circ} \mathrm{C}\right)$, moisture adjustment $(50 \%-70 \%)$, assay temperature $\left(40-80^{\circ} \mathrm{C}\right)$, aeration (250-1000 ml conical flasks), amount of seed (inoculum) 25$100 \mathrm{mg}$ and various nitrogen sources for optimum pectinase production were studied.

\section{Results and discussion}

\section{Screening of pectinase producing fungi}

In this study a total of twelve fungi were screened for the pectinase production. Fig. 1 indicates that the isolate $\mathrm{P}-8$ produced high pectinase activities $(405 \mathrm{U} / \mathrm{g})$, followed by $\mathrm{P}-10$ (392 U/g), P-12 (377 U/g), P-5 (364 U/g), P-4 (343 U/g) and $\mathrm{P}-2(324 \mathrm{U} / \mathrm{g})$, respectively. This isolate P-8 was identified as Aspergillus niger IM09 by microscopic study. This culture was used for the optimization of pectinase production using solid substrate culturing in different conditions. Due to the constraint of time we focused solely on the study of P-8 in our subsequent investigations.

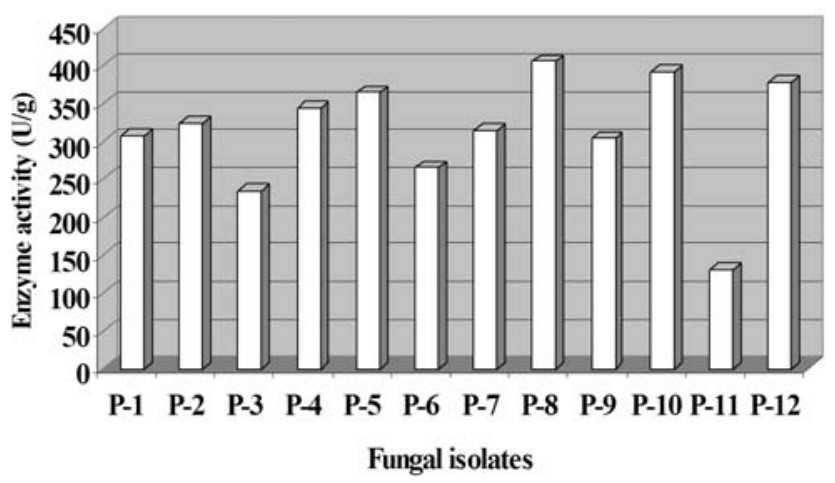

Fig. 1. Pectinase activity of different fungal isolates from solid state culture

Optimization of the selected fungal strain

Concentration of Pectin (as the soul source of carbon) optima for the enzyme

Addition of different amount of commercial pectin (1-5 g) in the production media on the pectinase production was studied. The addition of $2 \mathrm{~g}$ pectin to the production media resulted in marked increase in pectinolytic activities producing maximum $521 \mathrm{U} / \mathrm{g}$ of pectinase. The enzyme production however was strongly repressed by the addition of 3, 4 and 5 g pectin, showing $424 \mathrm{U} / \mathrm{g}, 372 \mathrm{U} / \mathrm{g}$ and only $205 \mathrm{U} / \mathrm{g}$ of pectinase activities, respectively (Fig. 2). The further inves- 
tigation was carried out at $2 \mathrm{~g}$ pectin level, varying the other parameters such as temperature, incubation period, etc.

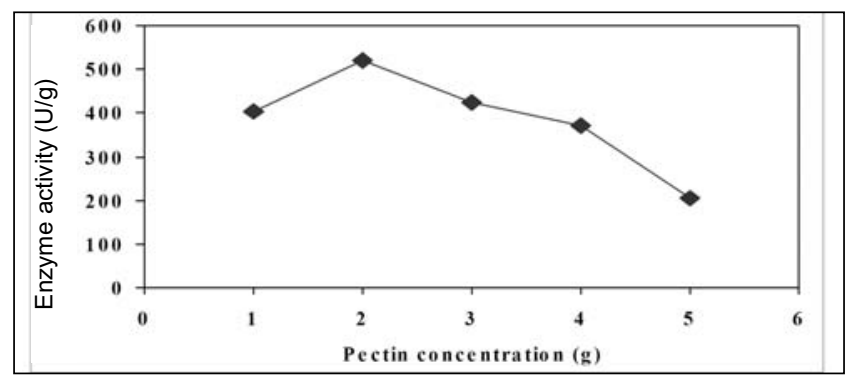

Fig. 2. Effect of pectin concentration on pectinase production

\section{Effect of incubation period on enzyme activity}

The results (Fig. 3) showed that three days incubation was most suitable for maximum pectinase activity $(524 \mathrm{U} / \mathrm{g})$ followed by two days incubation $(403 \mathrm{U} / \mathrm{g})$. With the increase in incubation period, a sharp decrease in enzyme activity was observed i.e. in 4th, 5th, 6th, 7th and 8th days showing $337 \mathrm{U} / \mathrm{g}, 248 \mathrm{U} / \mathrm{g}, 164 \mathrm{U} / \mathrm{g}, 147 \mathrm{U} / \mathrm{g}$ and $123 \mathrm{U} / \mathrm{g}$ of pectinase activity.

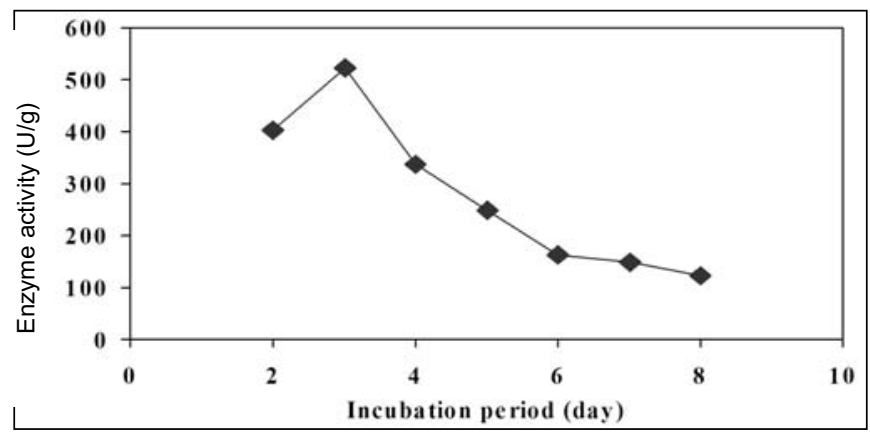

Fig. 3. Effect of incubation period on pectinase production

\section{Effect of temperature on enzyme activity}

The results in Fig. 4 showed that the flasks containing assay media after cultivation supported maximal pectinase (647 $\mathrm{U} / \mathrm{g}$ ) activity at $40^{\circ} \mathrm{C}$, followed by $583 \mathrm{U} / \mathrm{g}$ (at $35^{\circ} \mathrm{C}$ ), 516 $\mathrm{U} / \mathrm{g}\left(\right.$ at $30^{\circ} \mathrm{C}$ ), $515 \mathrm{U} / \mathrm{g}\left(\right.$ at $45^{\circ} \mathrm{C}$ ) and $392 \mathrm{U} / \mathrm{g}$ (at $50^{\circ} \mathrm{C}$ ), respectively.

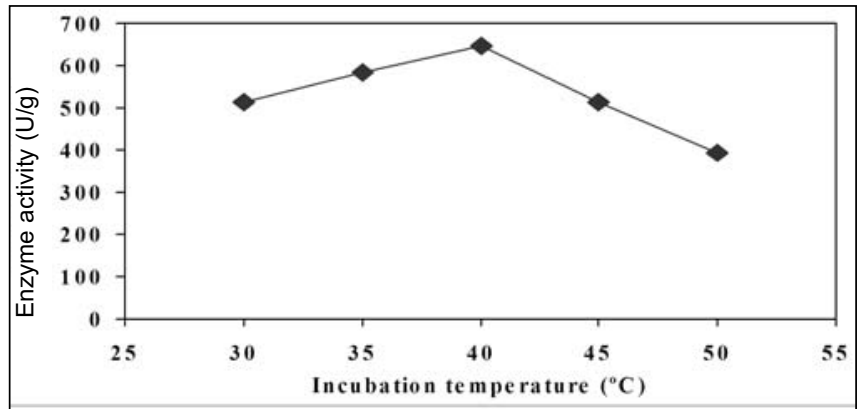

Fig. 4. Effect of temperature on pectinase production

\section{Effect of Moisture for enzyme production}

The results (Fig. 5) showed that the adjustment of $70 \%$ moisture to the production media resulted in a maximum pectinolytic activity of $648 \mathrm{U} / \mathrm{g}$ of, followed by $614 \mathrm{U} / \mathrm{g}$ (at $80 \%$ ), $595 \mathrm{U} / \mathrm{g}$ (at 90\%), $593 \mathrm{U} / \mathrm{g}$ (at 60\%) and $527 \mathrm{U} / \mathrm{g}$ (at 50\%), respectively. Pectinase activity gradually increased till $70 \%$ of moisture adjustment and then decreased till $90 \%$.

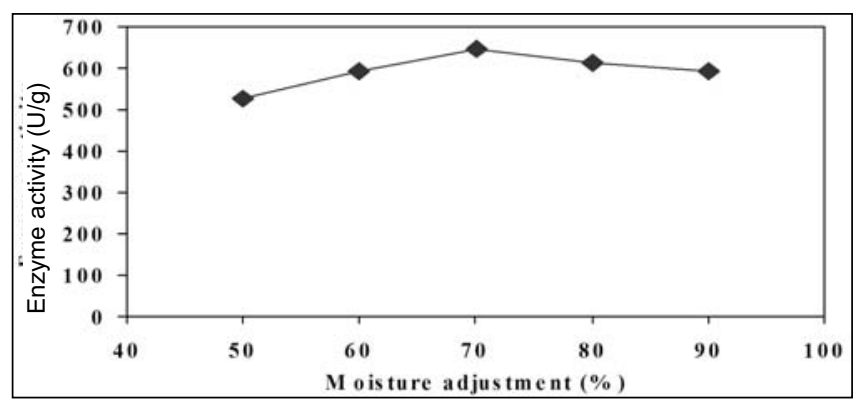

Fig. 5. Effect of moisture adjustment on pectinase production

Effect of assay temperature on enzyme activity

The results (Fig. 6) showed that the enzymatic activity was most suitable at assay temperature of $40^{\circ} \mathrm{C}$ for maximum pectinase activity $(651 \mathrm{U} / \mathrm{g})$ followed by $50^{\circ} \mathrm{C}(572 \mathrm{U} / \mathrm{g})$. With the increase in temperature the decrease was pronounced. This is evident from the fact that incubating the enzyme at $80^{\circ} \mathrm{C}$ for $10 \mathrm{~min}$ resulted in $45 \%$ loss of activity.

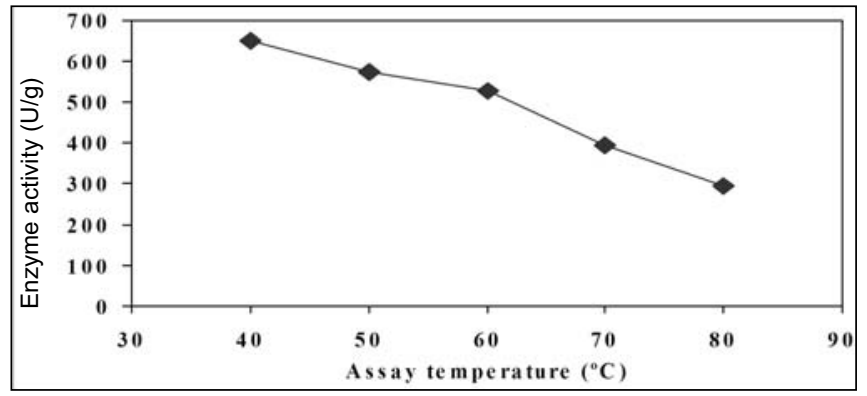

Fig. 6. Effect of assay temperature on pectinase production 


\section{Effect of aeration for the enzyme production}

The results in Fig. 7 showed that the flasks containing assay media after cultivation supported maximal pectinase (755 $\mathrm{U} / \mathrm{g}$ ) activity in $1000 \mathrm{ml}$ conical flask, followed by $677 \mathrm{U} / \mathrm{g}$ (750 ml conical flask), $638 \mathrm{U} / \mathrm{g}$ (500 ml conical flask), 578 $\mathrm{U} / \mathrm{g}$ (250 $\mathrm{ml}$ conical flask), respectively.

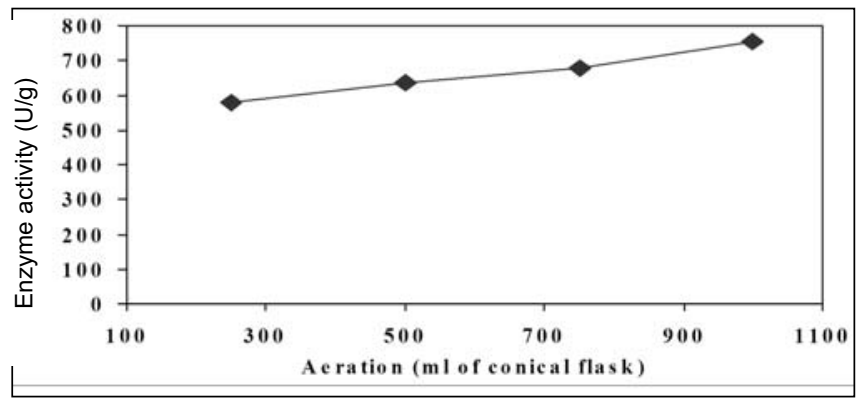

Fig. 7. Effect of aeration on pectinase production

Optimum amount of seed for the enzyme production

The results in Fig. 8 showed that the flasks containing $50 \mathrm{mg}$ of seed inoculated in assay media after cultivation supported maximal pectinase $(819 \mathrm{U} / \mathrm{g})$ activity, followed by $739 \mathrm{U} / \mathrm{g}$ (25 mg seed), $697 \mathrm{U} / \mathrm{g}(75 \mathrm{mg}), 466 \mathrm{U} / \mathrm{g}(100 \mathrm{mg})$, respectively.

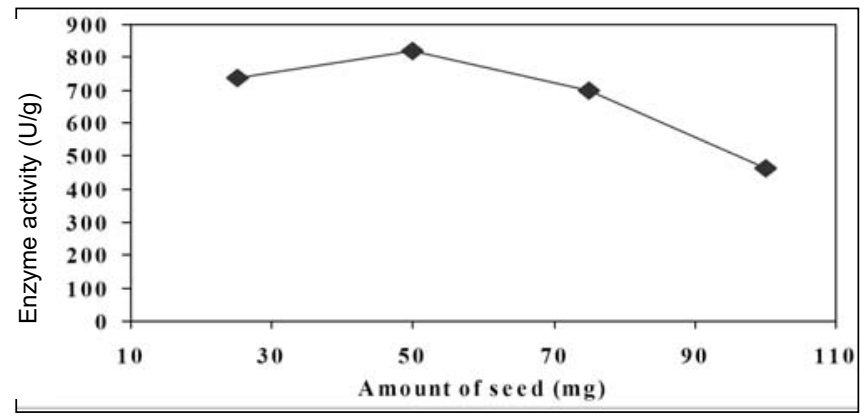

Fig. 8. Effect of amount of seed on pectinase production

\section{Effect of nitrogen sources on enzyme activity}

Various nitrogen sources used in the assay media (Fig. 9), yeast extract in combination with $\left(\mathrm{NH}_{4}\right)_{2} \mathrm{SO}_{4}$ was found to support maximal production of pectinase $(831 \mathrm{U} / \mathrm{g})$ followed by urea and $\left(\mathrm{NH}_{4}\right)_{2} \mathrm{SO}_{4}(761 \mathrm{U} / \mathrm{g}),\left(\mathrm{NH}_{4}\right)_{2} \mathrm{NO}_{3}$ and $\left(\mathrm{NH}_{4}\right)_{2} \mathrm{SO}_{4}(532 \mathrm{U} / \mathrm{g})$ and peptone and $\left(\mathrm{NH}_{4}\right)_{2} \mathrm{SO}_{4}(417$ $\mathrm{U} / \mathrm{g})$, respectively. Here, $\mathrm{AS}=(\mathrm{NH} 4)_{2} \mathrm{SO}_{4}, \mathrm{AN}=$ $\left(\mathrm{NH}_{4}\right)_{2} \mathrm{NO}_{3}, \mathrm{YE}=$ Yeast extract, $\mathrm{U}=$ Urea and $\mathrm{P}=$ Peptone. All (i.e. AS, AN, YE \& U) were used as $1.3 \mathrm{~g}$ in the assay media.

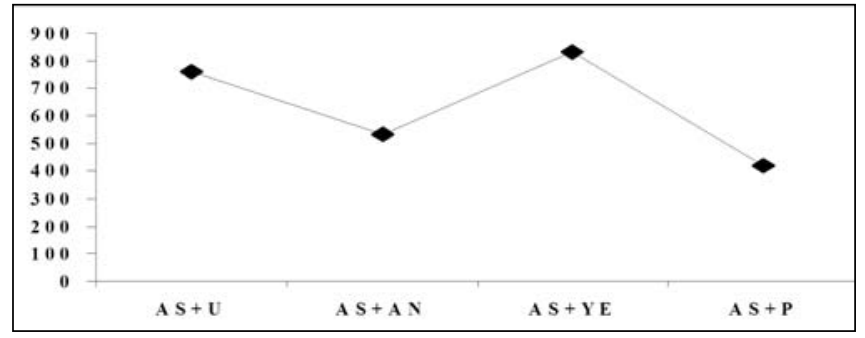

Fig. 9. Effect of nitrogen sources on pectinase activity

In the present study, the isolate P- 8 was found to be a potential source of pectinolytic enzymes and this isolate was identified as Aspergillus niger IM09 by microscopic study and selected for further experiment.

In the investigation, pectin is used as an inducer and the sole carbon source, similar to that reported by Fontana et. al. (2005) and Maldonado and Strasser de Saad (1998) with $A$. niger. The result showed that pectinase activity was increased $(521 \mathrm{U} / \mathrm{g})$ up to $2 \mathrm{~g}$ addition of pectin markedly from $1 \mathrm{~g}$ addition $(405 \mathrm{U} / \mathrm{g})$. But the enzyme activity decreased continuously till $5 \mathrm{gm}$ addition, showing activity of 424, 372 and 205 (U/g) for 3, 4 and $5 \mathrm{~g}$, respectively, similar to Galiotou et. al., (1996) who reported that higher pectin concentrations caused retardation of fungus growth and enzyme production. These results also might be indicative of an enzymatic repression, probably due to the presence of some pectin degradation products which act as enzyme inhibitors or different molecular forms of the pectinase sensible to these compounds, as observed by Maria et. al., (2000); Leone and Van der Heuvel (1987) and Malvessi and Silveira (2004).

The period of incubation depends upon the nature of the medium, fermenting organism, concentration of nutrients and the process physiological conditions (Sarvamangala and Dayanand, 2006). The present study showed that three days $(72 \mathrm{~h})$ incubation was most suitable for maximum pectinase activity (524 U/g) supported by Acuna-Argulles et. al, (1995); Linde et. al., (2007); Baracat et. al., (1989) and Castilho et al. (2000) and better than that found by Friedrich et. al., 1989 (95 hour). Sarvamangala and Dayanand (2006) observed that the period of fermentation in synthetic medium by pectinolytic fungi vary from 48 to $72 \mathrm{~h}$ and this observation is supported by Shivakumar and Krishnanand (1995), Solis-Pereira et. al., (1996) and Pandey (1991). So, the max- 
imum pectinase enzyme production at 3 days $(72 \mathrm{~h})$ in the present study indicates that it is suitable from the commercial point of view (Phutela et. al., 2005). Incubation temperature has been found to be a significant factor for enzyme production (Kitpreechavanich et. al., 1984). The results in the present study showed that the flasks containing assay media after cultivation supported maximal pectinase (647 $\mathrm{U} / \mathrm{g}$ ) activity at $40^{\circ} \mathrm{C}$ followed by $583 \mathrm{U} / \mathrm{g}$ (at $35^{\circ} \mathrm{C}$ ), $516 \mathrm{U} / \mathrm{g}$ (at $30^{\circ} \mathrm{C}$ ), $515 \mathrm{U} / \mathrm{g}$ (at $45^{\circ} \mathrm{C}$ ) and $392 \mathrm{U} / \mathrm{g}\left(\right.$ at $50^{\circ} \mathrm{C}$ ), respectively. The results showed that this pectinase producing fungal strain is more thermo-tolerant $\left(40^{\circ} \mathrm{C}\right)$ than other findings by Tuttobello and Mill (1961); Ueda et. al. (1982); Maldonado and Callieri (1989) who showed their pectinase producing fungi grow at $30^{\circ} \mathrm{C}$ and similar to the results of Larios et al. (1989), Bailey (1990), Baracat et. al. (1991) and Angayarkanni et. al., (2002) (at $\left.40^{\circ} \mathrm{C}\right)$.

Moisture adjustment varied at different cultural conditions. Excess moisture may contaminate the media by supporting the growth of bacteria and virus and low moisture content suppress the growth of pectinase producing fungal strain. The results showed that the adjustment of $70 \%$ moisture to the production media resulted in increase in pectinolytic activities producing maximum $648 \mathrm{U} / \mathrm{g}$ of pectinase activity which is supported Silva et. al. (2005) and Krishna and Chandrasekaran (1996) and Kashyap et. al. (2002) but not similar to the result observed Linde et. al., (2007).

In the present findings, maximum pectinase activity of 651 $\mathrm{U} / \mathrm{g}$ was observed at assay temperature of $40^{\circ} \mathrm{C}$ followed by $50^{\circ} \mathrm{C}(572 \mathrm{U} / \mathrm{g}) 60^{\circ} \mathrm{C}(527 \mathrm{U} / \mathrm{g}), 70^{\circ} \mathrm{C}(392 \mathrm{U} / \mathrm{g})$ and $80^{\circ} \mathrm{C}$ $(293 \mathrm{U} / \mathrm{g})$. This highest enzyme activity at $40^{\circ} \mathrm{C}$ supports the result observed by Galiotou et al., (1996). But after $40^{\circ} \mathrm{C}$, enzyme activity was decreased up to $80^{\circ} \mathrm{C}$. So, with the increase in temperature the decrease of enzyme activity was pronounced and this result supports Acuna-Argulles et. al. (1995) who reported that at higher temperatures $\left(50^{\circ} \mathrm{C}\right.$ or more) all enzymatic activities decreased after the incubation time in solid-state fermentation (SSF) . Moreover, this is evident from the fact that incubating the enzyme at $80^{\circ} \mathrm{C}$ resulted in $45 \%$ loss of activity compared to the enzyme activity at $40^{\circ} \mathrm{C}$ and is quite similar to the observation of Phutela et. al. (2005) who reported only $25 \%$ loss of enzyme activity at $80^{\circ} \mathrm{C}$ incubation did not support the result in the case of optimum temperature for optimum enzyme activity compared to the present study.

Aeration affected fungal growth (Dekker and Barbarosa, 2001). The results showed that the flasks containing assay media after cultivation supported maximal pectinase (755 $\mathrm{U} / \mathrm{g}$ ) activity in $1000 \mathrm{ml}$ conical flask Enzyme activity was increased $24 \%$ at $1000 \mathrm{ml}$ conical flasks ( $755 \mathrm{U} / \mathrm{g}$ ) compared to $250 \mathrm{ml}$ conical flasks $(578 \mathrm{U} / \mathrm{g})$. The present study clearly indicates that pectinase activity of the fungus was quite actively increased with increasing rate of aeration and supports the results obtained by Linde et. al., (2007); Mitchell et. al., (2003) and Santos et. al., (2004). This result also indicates that growth and activity of the fungi (Aspergillus niger) is quite effective in optimum aerobic condition supported by Venugopal et. al., (2007).

In the present study, the results showed that the flasks containing $50 \mathrm{mg}$ of seed inoculated in assay media after cultivation supported maximal pectinase $(819 \mathrm{U} / \mathrm{g})$ activity, followed by $739 \mathrm{U} / \mathrm{g}$ (25 mg seed), $697 \mathrm{U} / \mathrm{g}(75 \mathrm{mg}), 466 \mathrm{U} / \mathrm{g}$ $(100 \mathrm{mg})$, respectively. The enzymatic activity increased up to $50 \mathrm{mg}$ inoculum addition in the solid-state culture but then decreased continuously showing the activity of $697 \mathrm{U} / \mathrm{g}$ and $466 \mathrm{U} / \mathrm{g}$ by the inoculation of $75 \mathrm{mg}$ and $100 \mathrm{mg}$ inoculum, respectively in the assay media. The reason of decreasing activity would be due to the substrate of enzyme and initial amount of spores used as inoculum which is observed and supported by Alana et. al., (1989) the substrate (16 g wheat bran and $6 \mathrm{~g}$ rice husk) in the assay media was not sufficient for greater amount of inoculum (for 75 and $100 \mathrm{mg}$ ) as substrate.

In the present study, $\left(\mathrm{NH}_{4}\right)_{2} \mathrm{SO}_{4}$ with Yeast extract showed the highest enzyme activity $(831 \mathrm{U} / \mathrm{g})$ followed by $\left(\mathrm{NH}_{4}\right)_{2} \mathrm{SO}_{4}$ with Urea $(761 \mathrm{U} / \mathrm{g}), \quad\left(\mathrm{NH}_{4}\right)_{2} \mathrm{SO}_{4}$ with $\left(\mathrm{NH}_{4}\right)_{2} \mathrm{NO}_{3}(532 \mathrm{U} / \mathrm{g})$ and $\left(\mathrm{NH}_{4}\right)_{2} \mathrm{SO}_{4}$ with peptone $(418$ $\mathrm{U} / \mathrm{g}$ ) in the given order. The important findings in this study is that the yeast extract is the most useful nitrogen supplement for optimum productivity of the pectinase enzyme comparing to urea, $\left(\mathrm{NH}_{4}\right)_{2} \mathrm{NO}_{3}$ and peptone. The result of the highest enzymatic activity $(532 \mathrm{U} / \mathrm{g})$ by addition of yeast extract $+\left(\mathrm{NH}_{4}\right)_{2} \mathrm{SO}_{4}$ is similar to the results investigated by Boccas et. al., (1994), Aguilar and Huitron (1990); Galiotou et. al., (1996) and Larios et. al., (1989) and specially supported by Phutela et. al., (2005). 


\section{Conclusion}

The study has highlighted that the novel Aspergillus niger IM09 isolate is a good source for producing pectinases on cheap carbon source in short incubation period during solidstate of cultivation. The produced pectinases are catalytically active at rather high temperature and low pH. Further study will be carried out on the production, characterization and purification of pectinases for the industrial use of this highly demanding enzyme in Bangladesh as well as all over the world. This fungal strain could be considered under genetic modification for enormous production of pectinolytic enzymes, pectinase.

\section{References}

Acuna-Argulles M, Gutierez-Rojas M, Vinicgra-Gonzalez G and Favell-Torres E (1995), Production and properties of three pectinolytic activities produced by Aspergillus niger by submerged and solid state fermentation. Appl. Microbiol. Biotechnol. 43: 803-814.

Aguilar G and Huitron C (1990), Constitutive exo pectinase produced by Aspergillus sp. CH-Y-1043 on diVerent carbon source. Biotechnol. Lett. 12(9): 655-660.

Alana A, Gabilondo A, Hernando F, Moragues MD, Dominquez J.B, Liama MJ and Sessa JL (1989), Pectin lyase production by a Penicillium italicum strain. Appl. Environ. Microbiol. 55: 1612-1616.

Angayarkanni J, Palaniswamy M, Murugesan S and Swaminathan K (2002), Improvement of Tea Leaves Fermentation with Aspergillus spp. Pectinase. Journal of Bioscience and Bioengineering. 94(4):299-303.

Bailey MJ (1990), Effects of temperature on polygalacturonase production by Aspergillus niger. Enzyme Microb. Technol. 12: 622-624.

Baneke ES and Rogers AL (1970), Medical Mycology Manual. 3rd ed. Burgress Publishing Companies. Minneapolis.

Baracat MC, Vaneti MCD, Fernades E and Silva DO (1991), Growth conditions of a pectinolytic Aspergillus fumigatus for degumming of natural fibres. Biotechnol. Lett. 13:693-696.
Baracat MC, Valentti MC, Muchovej JJ, Araujo EF and Silva DO (1989), Selection of a pectinolitic fungi for deguming of natural fibers. Biotechnol. Lett. 11: 899-702.

Boccas F, Roussos S, Gutierrez M, Serrano L and Viniegra GG (1994), Production of pectinase from coffee pulp in solid-state fermentation system: selection of wild fungal isolate of high potency by a simple three-step screening technique. J. Food Sci. Technol. 31(1): 2226.

Castilho LR, Alves LM and Medronho RA (1999), Recovery of concentrate. Proc. Fla. State Hort. Soc. 94: 270-273.

Casthilo L, Medronho RA and Alves TLM (2000). Production and extraction of pectinase obtained by solid state fermentation of agroindustral residues with Aspergillus niger. Bioresour. Technol. 71: 45-50.

Dekker RFH and Barbosa AM (2001), The effect of aeration and veratryl alcohol on the production of two laccases by the ascomycete Botryosphaeria sp. Enzyme Microb. Technol. 28: 81-88.

Fontana RC, Salvador S and Silveira MM (2005), Influence of pectin and glucose on growth and polygalacruronase production by Aspergillus niger in solid-state cultivation. J. Ind. Microbiol. Biotechnol. 32(8): 371-377.

Friedrich J, Cimerman A and Steiner W (1989), Submerged production of pectolytic enzymes by Aspergillus niger: effect of different aeration/agitation regimes. Applied Microbiol. Biotechnol. 31: 490-494.

Galiotou-Panayotou M, Kapantai M and Klantzi O (1996), Growth conditions of Aspergillus sp. ATHUM-3482 for polygalacturonase production. Appl Microbiol. Biotechnol. 47: 425-429.

Hang C and Dornenburg H (2000), Perspectives in the biological function and the technological application of polygalacturonases. Appl. Microbiol. Biotechnol. 53: 366-375.

Kashyap DR, Soni SK and Tewari R (2002), Enhanced production of pectinase by Bacillus sp. DT7 using solid state fermentation. Bioresource Technology. 88(3): 251-254. 
Kitpreechavanich V, Hayashi M and Nagai S (1984), Productionof xylan-degrading enzymes by thermophillic fungi, Aspergillus fumigatus and Humicola lanuginosus. J. Ferment. Technol. 62: 63-69.

Krishna C and Chandrasekaran M (1996), Banana waste as substrate for $\alpha$-amylase production by Bacillus subtilis (CBTK 106) under solid-state. Applied Microbiology and Biotechnology. 46(2): 106-111.

Larios G, Garcia JM and Huitron C (1989), Endo-polygalacturonase production from untreated lemon peel by Aspergillus sp. CH-Y-1043. Biotechnol Lett. 11: 729-734.

Leone G and Van den Heuvel J (1987), Regulation by carbohydrates of the sequential in vitro production of pectic enzymes by Botrytis cinera. Can. J. Bot. 65: 21332142.

Linde GA, Magagnin G, Costa JAV, Bertolin TE and Colauto NB (2007), Column bioreactor use for optimization of pectinase production in solid substrate cultivation. Brazilian Journal of Microbiology. 38: 557-562.

Maldonado MC and Callieri DAS (1989), Influence of environmental conditions on the production of pectinesterase and polygalacturonase by Aspergillus niger. World Journal of Microbiology and Biotechnology. 5(3): 327-333.

Maldonaldo MC and Strasser de Saad AM (1998). Production of pectinesterase and polygalacturonase by Aspergillus niger in submerged and solid state system. J. Ind. Microbiol. Biotechnol. 20(1): 34-38.

Malvessi E and Silveira MM (2004), Influence of medium composition and $\mathrm{pH}$ on the production of polygalacturonaseby Aspergillus oryzae. Braz. arch. biol. Technol. 47(5).

Maria FST, Jose LLF and Nelson D (2000), Carbon sources effect on pectinase production form Aspergillus japonicus 586. Braz. J. Microbiol. 31(4).

Mitchell DA, Meien OFV and Krieger N (2003), Recent developments in modeling of solid-state fermentation heat and mass transfer in bioreactors. Biochem. Eng. J. 13: $137-147$.
Nikolov A (2003), Enzymes-an industry standard. Textile Technology International. p46.

Nielsen PH (1991), Enzyme applications (industrial) in Kirk-Othmer Encyclopedia of Chemical Technology. Fourth ed. 9: 567-620.

Pandey A (1991), Effect of particle size of substrate on enzyme production in solid-state fermentation. Bioresour. Technol. 37: 169-172.

Phutela U, Dhuna V, Sandhu S and Chadha BS (2005), Pectinase and Polygalacturonase production by a thermophillic Aspergillus Fumigatus isolated from decomposting orange peels. Brazilian Journal of Microbiology. 36(1): 63-69.

Santos MM, Rosa AS, Dal'Boit S, Mitchell D and Krieger N (2004), Thermal denaturation: is solid-state fermentation really a good technology for the production of enzymes? Bioresour. Technol. 94: 261-268.

Sarvamangala RP and Dayanand A (2006), Production of pectinase from deseeded sunflower head by Aspergillus niger in submerged and solid-state conditions. Bioresource Technology. 97: 2054-2058.

Shivakumar PD and Krishnanand (1995), Anaerobic degradation of pectin by mixed consortia and optimization of fermentation parameters for higher pectinase activity. Lett. Appl. Microbiol. 20: 117-119.

Silva D, Tokuioshi K, Martins EDS, Silva RD and Gomes E (2005), Production of pectinase by solid-state fermentation with Penicillium viridicatum RFC3. Process Biochemistry. 40(8): 2885-2889.

Solis-Pereira S, Favela-Torres E, Viniegra-González G and Gutiérrez-Rojas M (1993), Effects of different carbon sources on the synthesis of pectinase by Aspergillus niger in submerged and solid state fermentation. Appl. Microbiol. Biotechnol. 39: 36-41.

Spanga G, Pefferi PG and Gillali E (1995), Immobilization of a pectin lyase from Aspergillus niger for Application in food technology. Enzyme Microb. Technol. 17: 729738. 
Stiles HR, Peterson WH and Frid EB (1926), Estimation of reducing sugar. J. Bact. 12: 427-430.

Taragano V, Sachez VE and Pilosof AMR (1997), Combined effect of water activity depression and glucose addition on pectinases and pectinase production by Aspergillus niger. Biotechnol. Lett. 19: 233-236.

Tuttobello R and Mill PJ (1961), The pectic enzymes of Aspergillus niger. Biochem J. 79: 51-64.

Ueda S, Yusaku F and Lim JY (1982), Production and some properties of pectic enzymes from Aspergillus oryzae A-3. J Appl Biochem. 4: 524-532.
Venugopal C, Jayachandra T and Anu Appaiah KA (2007), Effect of Aeration on the Production of Endo-Pectinase from Coffee Pulp by a Novel Themophillic Fungi Mycotypha sp. Strain No. AKM 1801. Biotechnology. 6(2): 245-250.

White JS and White DC (1971), Source Book of Enzymes. Boca Raton: CRC Press.

Yoshikawa K and Tsuetaki H (1997), Hakkokogaku Kaishi. 57: 467.

Received: 17 July 2011; Revised: 10 January 2013; Accepted: 27 January 2013. 